ства, можно предположить, что появление подобного жития с миниатюрой характерно именно для книжного искусства Германии второй половины XII века, что также доказывает ряд близких по содержанию памятников.

\section{Список литературы}

1. De Norberto BSB Clm. 17144 [Электронный ресурс]. - Режим доступа: http://daten.digitale-sammlungen.de/ db/0006/ bsb00060102/images/

2. Klemm E. Die romanischen Handschriften der Bayerischen Staatsbibliothek: Die Bistümer Freisind und Augsburg, verschiedene deutsche Provenienzen / Wiesbaden, 1988. Bd.1.

3. Backmund N. Die mittelalterlichen Geschichtsschreiber des Prämonstratenserordens. - Averbode, 1972.
4. Handgratinger Th. Der heilige Norbert: Erzbischof und Ordensgrunder. - Magdeburg, 2011.

5. Halder K.H. Norbert von Xanten: der Grunder des Pramonstratenordens und seine Zeit. - Innsbruck, 2010.

6. Elm K. Norbert von Xanten. Bedeutung - Persönlichkeit Nachleben // Norbert von Xanten: Adliger, Ordensstifter, Kirchenf rst. Festschrift zum Gedächtnis seines Todes vor 850 Jahren. Elm, K. (Hg.).— Köln, 1984.

7. Stahlheber R. Die Ikonographie Norberts von Xanten. Themen und Bildwerke // Norbert von Xanten: Adliger, Ordensstifter, Kirchenf rst - Festschrift zum Gedächtnis seines Todes vor 850 Jahren. Elm, K. (Hg.) - Köln, 1984.

8. Ruf P. Die Handschriften des Klosters Schäftlarn // 1200 Jahre Kloster Schäftlarn 762-1962: Blätter zum Gedächtnis. Mitterer, S (Hg.). — München, 1962.

удК 76; 7.04; 7.047

\title{
у.В. ЭЛИНСОН
}

\section{«ЖИВОПИСНОЕ ПУТЕШЕСТВИЕ ОТ МОСКВЫ ДО КИТАЙСКОЙ ГРАНИЦЫІ - ГРАФИЧЕСКИЕ АЛЬБОМЫ ПУТЕВЫХ ЗАРИСОВОК А.Е. МАРТЫНОВА (1768-1826)}

Рассматривается история создания графических альбомов и живописных произведений, выполненных А. Е. Мартыновым, по натурным зарисовкам, составленным во время путешествия 1805 года в составе Российского посольства в Китай под руководством графа Ю.А. Головкина.

Ключевые слова: акварели; альбом офортов; графика; живописное путешествие; пейзажная живопись; Российское посольство графа Ю. А. Головкина; типография Плюшара; пейзажист А.Е. Мартынов.

B начале XIX века по приказу Александра I одна за другой снаряжаются экспедиции с военно-стратегической целью осмотра дальних земель России. Это было время и великих кругосветных путешествий. В правительственных кругах Российской империи велись геополитические споры о том, какой быть будущей России - преимущественно континентальной или морской державой, какому направлению - восточному или западному - отдать приоритет во внешней политике. Важнейшим событием конца 1804 года стала организация экспедиции в Китай. Возглавил Российское посольство граф Юрий Александрович Головкин (1762-1846).

Сенатор при Павле I, а также президент Коммерцколлегии и обер-церемониймейстер при Александре I, Ю.А. Головкин был назначен чрезвычайным послом в Китай 17 февраля 1805 года. Головкину вменялось в обязанность обсудить новые торговые зоны в пограничных районах, упрочить статусное положение Российской духовной миссии в Китае, а также установить прочные торговые отношения между Россией и Китаем. Кроме того, экспедиция имела еще и познавательную цель собрать разного рода сведения о природных условиях Дальнего Востока и его народонаселении. Посольство было многочисленное, в него входили ученые, чиновники, военные и духовные лица. «Для снятия видов» были приглашены художники А.Е. Мартынов (1768-1826), И.П. Александров (1780-1822) и Т.А. Васильев (17831838). Андрей Ефимович Мартынов был приглашен 13 июля 1805 года в качестве главного художника Российского посольства. На тот момент он являлся совет- 
ником Императорской академии художеств. Путешествие по Сибири оказало огромное влияние на творчество Мартынова. Путь от Москвы до главного монгольского кочевья - Урги (ныне город Улан-Батор) - пролегал через Заволжье, Урал и Сибирь.

В ходе путешествия Мартыновым были выполнены натурные рисунки карандашом и тушью, которые впоследствии легли в основу нескольких графических циклов. Это серия акварелей «Виды России и Монголии. Из путешествия при Российском посольстве в Китай. 18061810 годы», включающая 23 листа; «Типы народов России и Монголии. Из путешествия при Российском посольстве в Китай» (1808, серия выполнена в технике мягкого лака и включает 39 листов), а также альбом из 29 акварелей «Живописное путешествие при Российском посольстве в Китай 1805 года» (1814-1819). Этот альбом лег в основу серии офортов «Живописное путешествие от Москвы до китайской границы». Графические листы сброшюрованы в альбомы, известные в восьми видах и отпечатанные в типографии А. Плюшара в 1819 году. Серия включает 31 лист, но в каждом из альбомов сброшюровано разное количество офортов. Кроме того, полученные впечатления стали источником ряда произведений, не связанных серийно. Позднее многие сюжеты нашли живописное воплощение.
Серии акварелей интересны тем, что листы расположены в соответствии с маршрутом посольства. Альбом в зеленом сафьяновом переплете с золотым тиснением открывается предисловием, в котором Мартынов дает подробные пояснения к каждой из акварелей. 0 н «убежден мыслию, что живопись действует сильнее и приятнее на воображение и зрение, когда знаешь историю и отличный интерес представленного кистью предмета» [1]. Действительно, пояснения обширны и содержательны, о чем свидетельствует уже первый разворот с изображением Московского Кремля и подробнейшим описанием истории создания его памятников. Последующие листы знакомят с географией путешествия. Это «Владимир на Клязьме», «Нижний Новгород с другой стороны Оки» и «Нижний Новгород при впадении Оки в Волгу» (рис. 1).

Последняя акварель демонстрирует новый подход художника к пейзажному построению. В этой работе нет привычной классицистичности мотива, с кулисами первого плана и открывающейся далью. Перспектива дали присутствует, но задача трактовки совсем иная. Очевидно, что художник пользовался натурными зарисовками - так естественно и убедительно передан широкий разлив двух рек. В самом центре листа он изображает Архангельский собор, со всем вниманием передавая детали архитектурного облика. Художник включает в изображение и жанро-

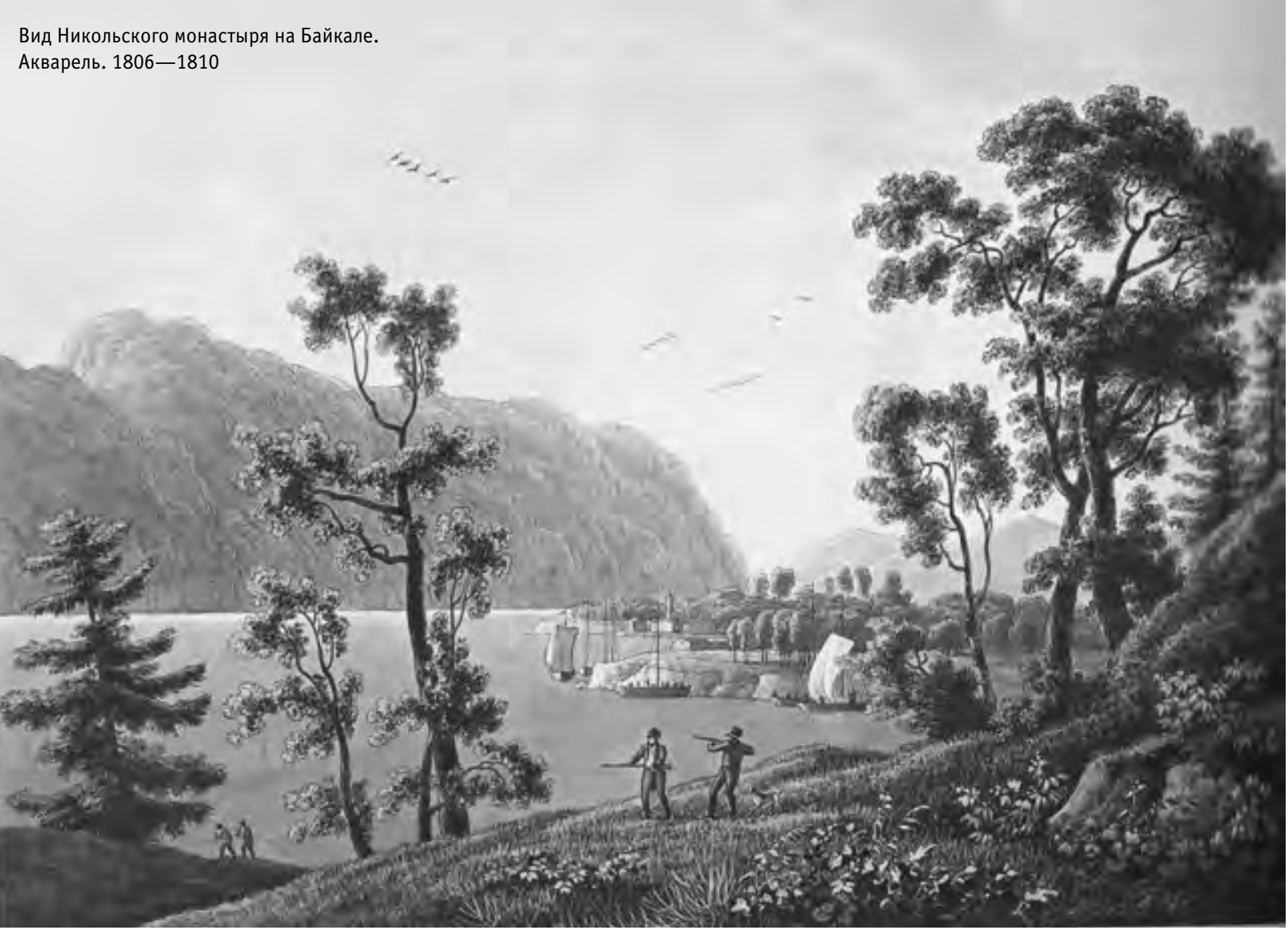


вый мотив, что придает ему жизненную убедительность. В акварели нет сочиненных красот, и это, без сомнения, является ее достоинством.

Мартынов хорошо чувствует особенности акварельной техники. Он в полном объеме использует средства художественной выразительности, характерные для этого вида графики. Прозрачными нежно-голубыми красками он пишет безоблачное небо, при этом умеет передать тончайшие тональные переходы: у горизонта небосвод светлеет, появляются белесые жемчужные тона. Линия горизонта местами сливается с небом, объединяя стихии воды и воздуха. Пейзаж второго плана пронизан ощущением воздуха и мягкого света, отчего первый план акварели производит впечатление большей весомости. Коричневатые, охристые краски составляют основу живописной гаммы, но первый план, особенно траву и мелкий кустарник, художник пишет яркой изумрудной зеленью. Это будет присутствовать и в других его акварелях. Тонким пером он прорисовывает отдельные ветви, листья, а краску, несмотря на то, что это техника акварельная, кладет корпусно, так что каждый мазок отчетливо воспринимается глазом.

Между 1810 и 1819 годами на этот сюжет Мартынов написал живописную работу. Картина носит название «Вид Нижнего Новгорода» и хранится в ГРМ. Архангель- ский собор, построенный по указу царя Михаила Федоровича архитекторами Лаврентием и Антипой Возоулиными к 1631 году, не случайно привлек внимание художника. Само по себе это место у слияния Оки и Волги очень живописно. От него взору открывается часть Нижегородского Кремля с его мощными стенами, но не менее важным был тот факт, что именно там находится усыпальница Козьмы Минина - героя Новгородской земли. В живописном варианте художник в самых малых деталях отступает от акварельного прототипа, и связано это было с изменением формата картины, которая в живописном варианте приблизилась к квадрату и в нее не вошла сторожевая башня кремля справа и здания, расположенные в этой части листа. В целом же основные изменения коснулись колористического решения. Мартынов использует сближенную гамму коричневых и охристых тонов, в картине нет пронзительной зелени травы на первом плане и чистой голубизны неба. Это, в принципе, не удивительно, так как в живописи художники стремились к большей цветовой уравновешенности.

Мартынов напишет вид Макарьева монастыря, и в первой серии есть акварель, изображающая ярмарку в этом городке.

Особый интерес представляет «Вид Казани» (Государственный Русский музей). Акварель «Казань»
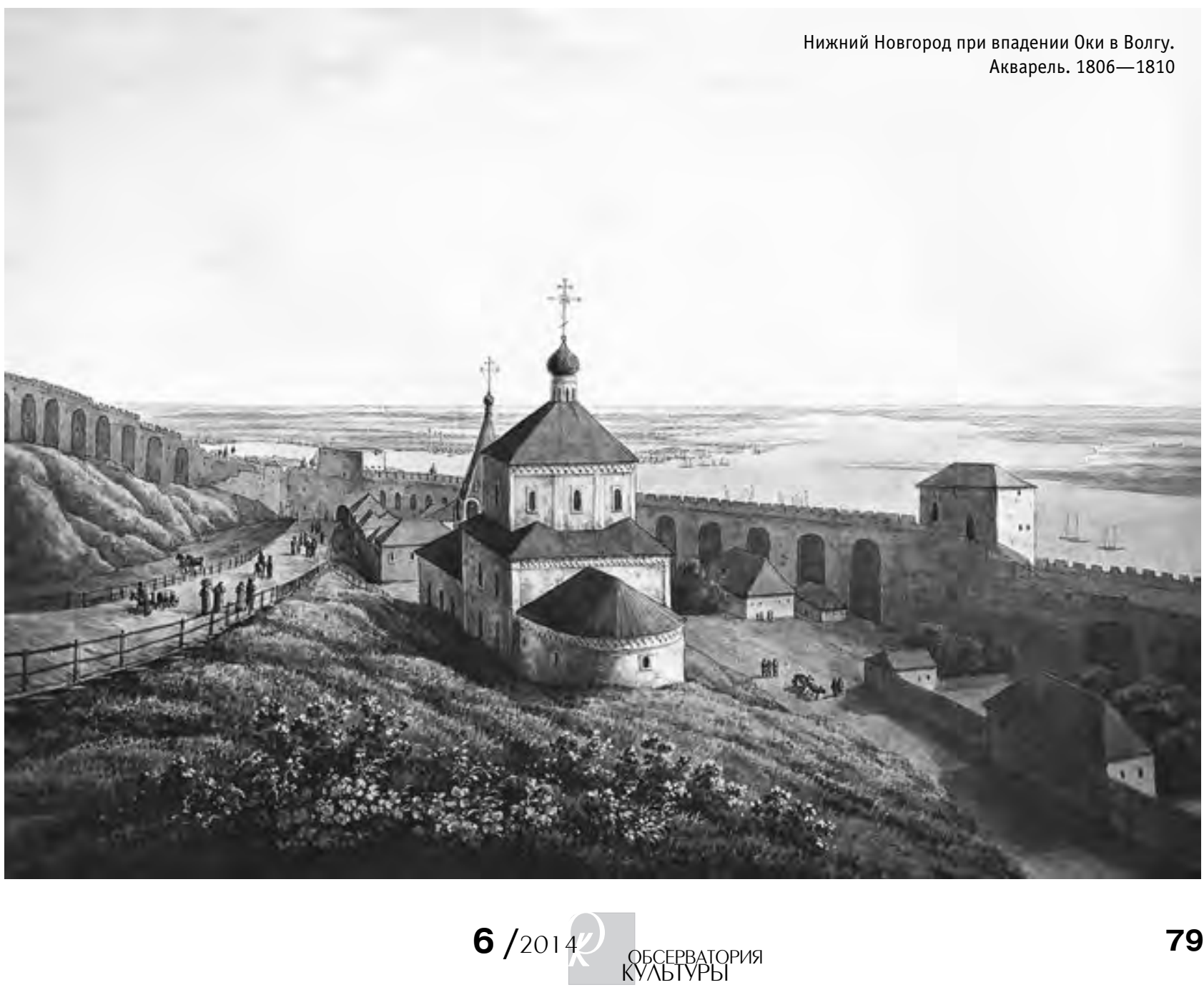
послужила основой для живописного произведения, написанного в 1816 году. Если сравнить эту живописную работу с предыдущей, становится очевидным, что художник обращается к той композиции, которая в большей степени характеризует его творчество на рубеже XVIII и XIX веков. Он выбирает традиционный «кабинетный» формат и использует кулисную систему построения. Первый план слева занимает высокое раскидистое дерево, которое вводит взгляд в картинное пространство. Мощные каменные валуны на первом плане чуть поросли мхами и мелкими белыми цветами. Это белое будет поддержано в живописи второго плана, где художник изображает пасущееся стадо. Пасторальная картинка невольно напоминает ранние работы художника. В акварели этот мотив решен с большей жанровой убедительностью и воспринимается как бытовой. Особый интерес представляет дальний план, где художник пишет Казанский кремль, расположенный на крутых холмах. Несмотря на удаленность городского пейзажа, можно видеть отдельные дома, улицы. В акварельном прототипе эти детали художник трактует тонким перовым рисунком. В живописной композиции при всей ее привлекательности присутствует момент несоответствия пасторального первого плана и городского пейзажа, трактованного с топографической убедительностью. Цветовое решение акварелей и живописной картины также различно. В акварелях больше цветовой насыщенности, что придает работам динамичность, жизненную убедительность.

Следуя топографии путешествия, художник исполняет виды Перми, Екатеринбурга, Томска. Изображая Томск, художник, как и в предыдущем случае, обращается к панорамному виду, когда первый план представляет собой пейзаж, а город можно увидеть вдали - на втором плане. Мартынов - пейзажист, и поэтому природный мотив так увлекает его. Весь первый план занимает изображение невысокого холма, откуда художник изучает вид города. Кустарник, невысокие деревья, растущие в низине, являются фоном для пасущихся коров и стаффажной группы, включающей мужчину, сидящего на косогоре, и стоящую рядом с ним женщину в ярком алом покрывале, которое прикрывает голову, лежит на плечах. Это красочное пятно живописно обогащает графический лист, позволяет почувствовать тонкие градации зеленого цвета, служащего основой живописной гаммы произведения. Зеленый цвет разработан художником сложно: местами он приобретает изумрудные оттенки, а в листве дерева, написанного справа и выполняющего роль кулис, приобретает охристые желтые оттенки. Особенно интересен он на фоне неба.

Изображая сам Томск, художник подчеркивает особенности ландшафта города, который делится рекой Томь на две части. Высокие берега густо населены, стройные силуэты церквей и колоколен придают панораме законченный вид.

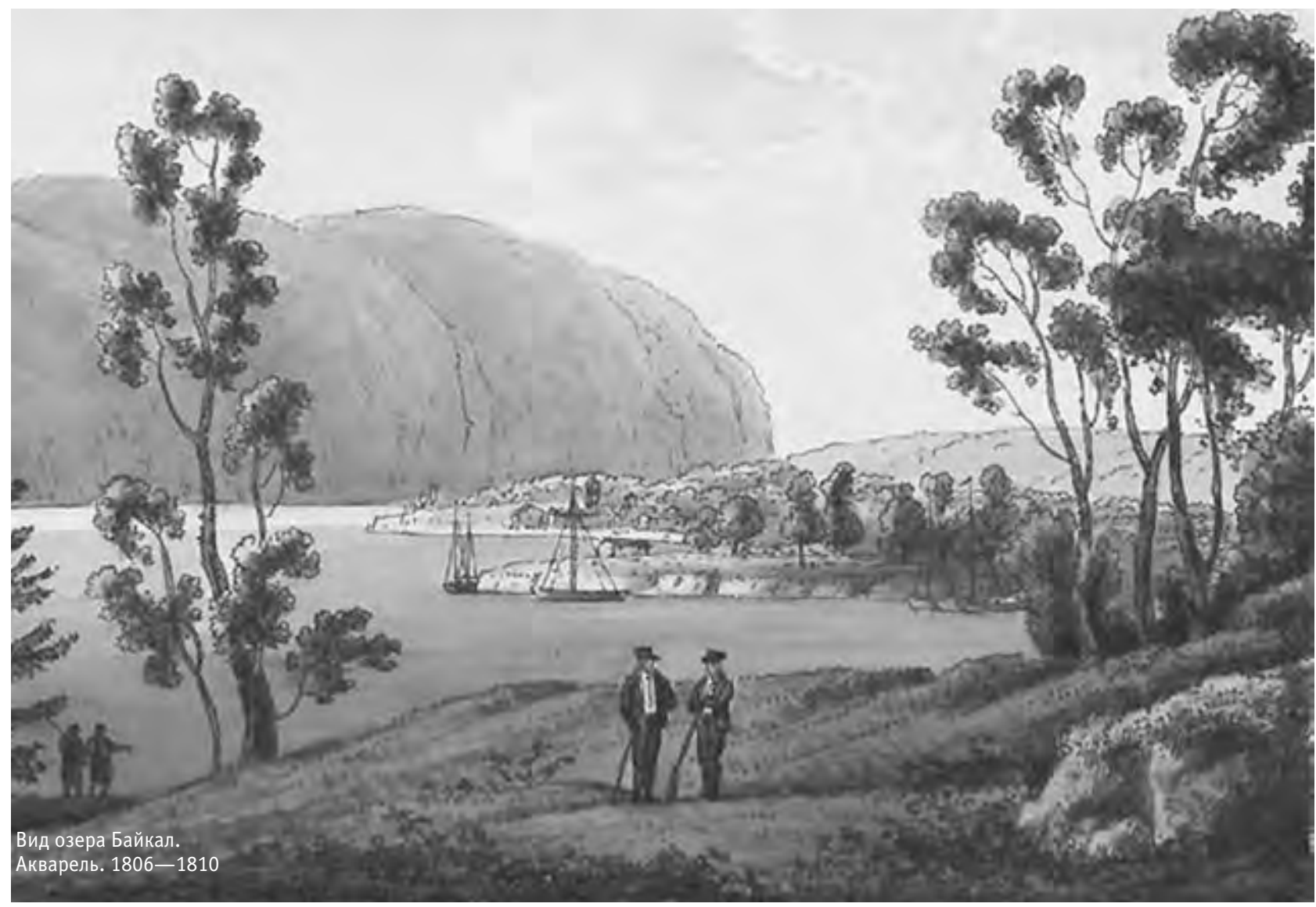


Красноярск Мартынов напишет несколько раз, так как посольство останавливалось в этом городе на длительный срок. В акварели «Вид Красноярска и реки Енисей» пейзажный мотив используется как доминирующий. Сам город едва угадывается вдали, а первый план представляет собой живописный берег Енисея, оживленный группой прогуливающихся персонажей. При изображении Томска художник в большей степени следовал традиционному пониманию композиции классицистического пейзажа. Он использует четкое деление на планы в колорите и кулисную систему. Здесь художник смело сопоставляет зелень деревьев и пронзительную голубизну вод Енисея у береговой линии.

Следующим пунктом длительной остановки посольства станет Иркутск, в те годы самый удаленный губернский город. Мартынов напишет несколько видов Иркутска: с парусниками на реке, со стадом у забора, с фигурами на берегу, сделает и панорамный вид, но самым любопытным будет факт создания нескольких жанровых сцен. Позже они были литографированы, и эта серия, включающая 6 листов, получила название «Бал в Иркутске» (1821-1824). Серия сохранилась в полном виде с раскраской акварелью в собрании Государственный Русский музей, 2 листа имеются в собрании Государственного музея изобразительных искусств им.А.С. Пушкина.

Из Иркутска посольство отбыло в Кяхту - русскую торговую слободу на границе с Китаем в Забайкалье, расположенную недалеко от китайского селения Маймачин. Путешествовали осенью, из Иркутска выехали 2 сентября, а 3 октября оказались у самой границы. В 1806 году в Петербурге было опубликовано «Письмо молодого художника из Кяхты к своему приятелю» [2]. А.А. Федоров-Давыдов ошибочно предполагал, что автором этого письма был Мартынов [3, с. 326], однако из текста явствует, что написано оно было кем-то из его молодых коллег: либо И.П. Александровым, либо Т.А. Васильевым. Представляется, что есть основания предположить авторство Васильева, так как он был пейзажистом, а описания природы выразительны и указывают на тонко чувствующего природный мотив человека. Уже в первых строках письма он пишет о трудностях, которые им пришлось претерпеть из-за неблагополучной погоды. Сначала пришлось ждать, пока успокоится озеро, но многие не избежали морской болезни. Автор письма сообщает о том, что перенести тяготы пути удалось только ему, Мартынову и еще двум чиновникам. Впрочем, непогода не помешала оставить первые записи о видах Байкала и его берегов: «сии горы покрыты вечными снегами, что делает для взора бесподобную, а для кисти неподражаемую картину» [2, с. 96].

Байкал вдохновил Мартынова на создание нескольких видов. На акварели «Байкал» (1810, Государственная Третьяковская галерея) художник изображает идиллический пейзаж с высокими лесистыми берегами, изящной

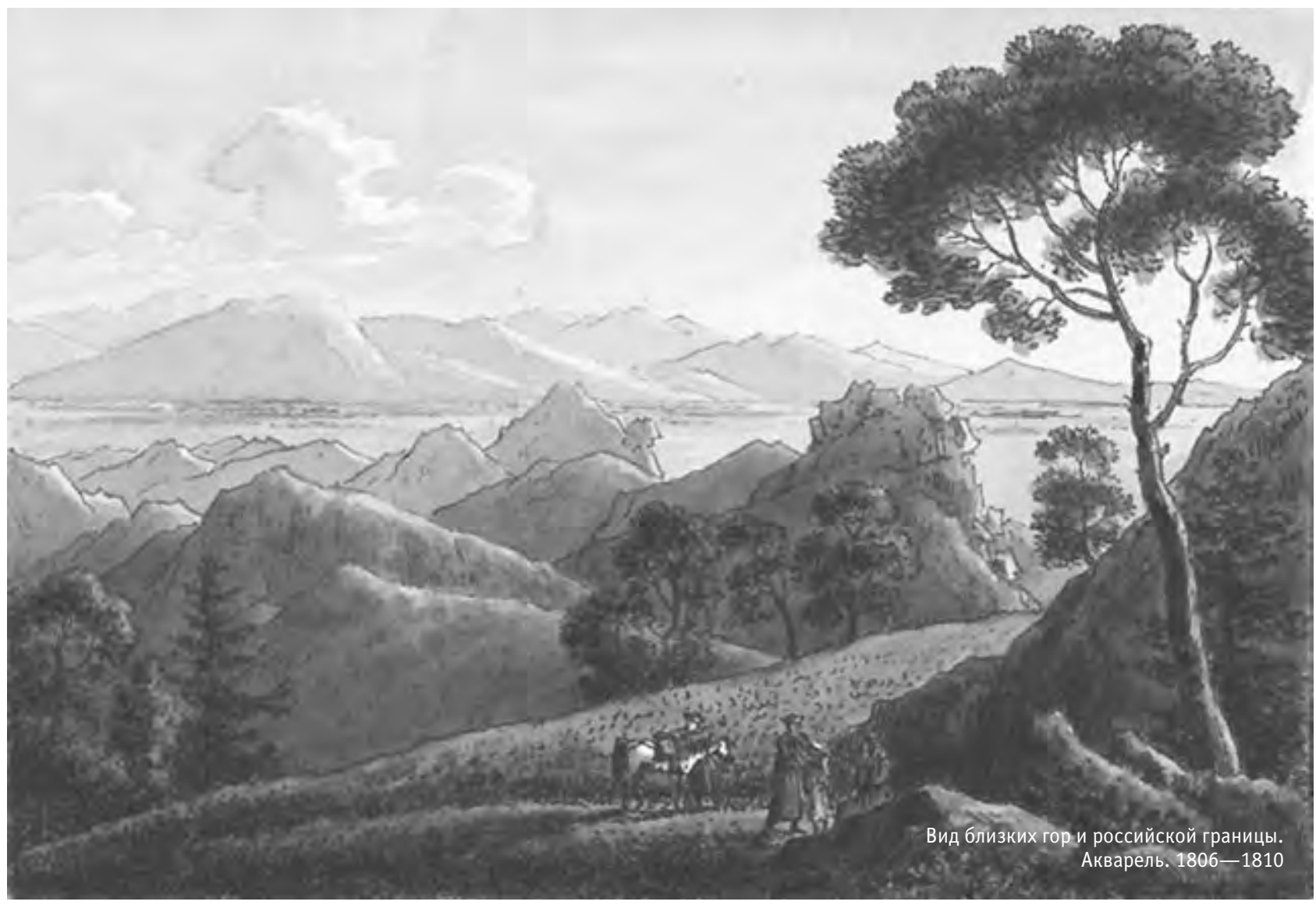


шхуной. В композицию включено несколько стаффажных групп. Вниманию зрителей представлена сцена с рыбаками, разгружающими улов, мужчиной и женщиной, прогуливающимися по дорожке, которая пробита в скале, а также двумя персонажами на первом плане. 0дин из них - босой крестьянин в длинной белой рубахе, а другой в синем армяке, подпоясанном широким поясом, в сапогах, с тростью в руке и картузом на голове. Такой мужчина в армяке как стаффажная фигурка будет неоднократно встречаться в этих сериях акварелей. Художник вновь демонстрирует мастерство владения акварельной техникой. Он использует самые нежные сочетания голубых, серебристо-серых, жемчужных тонов. Зелень пишет мягко, без той цветовой насыщенности, которая была характерна для первых акварелей серии. Это неудивительно, так как художник создает осенний пейзаж, и зелень высокого дерева приобрела охристую тональность. По мнению А.А. Федорова-Давыдова, в этом цикле работ Мартынову «лучше всего удаются изображения больших рек и гор», как характерный пример он называет акварель «Байкал» «с эллиптическим изгибом берега, замыкающими даль горами и гладкой зеркальной поверхностью озера» [3, c. 231] .

Под впечатлением от природы Байкальского края художник выполнит еще не один живописный пейзаж. Это, например, «Вид Байкала с Чуманского камня», известный по акварели, хранящейся в альбоме 1814-1819 годов. Живописная композиция «Вид Байкальского озера» (1814) хранится в Государственном Русском музее. В картине легко прослеживаются два плана: это берег озера со сценой травли охотничьими собаками сайгака, зеркалом озера в центре композиции и дальним планом с высокими берегами Байкала, Чуманским камнем слева, который мощным объемом выступает из золотисто-голубого марева последнего плана. В пейзаже присутствует романтический мотив, который, как это нередко бывает у Мартынова, в акварельном варианте воспринимается с большей жизненной достоверностью.

По композиции этим изображениям близок «Вид Никольского монастыря на Байкале» (1806-1810, Государственный Эрмитаж), который художник будет называть «Море Байкал» (рис. 2). Вновь первый план занимает природный мотив с высокими деревьями и жанровой сценой, изображающей охотников с ружьями, собаку. Сам Никольский монастырь - в глубине на втором плане, утопающий в легкой дымке. Помещение основного мотива пейзажа на втором плане было характерно для композиции классицистического пейзажа. В этом Мартынов следует традиции.

В Забайкалье он выполнит еще несколько пейзажей, изображающих виды реки Селенги. Одна из этих акварелей с небольшими изменениями послужила основой для создания в 1817 году картины «Вид реки Селенги в Сибири» (Государственная Третьяковская галерея).

Природа Забайкалья произвела на художника огромное впечатление. Мартынов оставил описание этих мест, которое можно найти в альбоме 1819 года, изданном А. Плюшаром: «Ничто не может быть прелестнее и величественнее берегов реки Селенги. Во многих местах они состоят из неприступных, крутых гор и утесов, похожих на разоренные и обрушающиеся стенные зубцы исполинских готических замков, образованных в тысяче различных видов... Напротив отголоски берегов покрыты прекрасными рощами, как будто искусною рукою нарочно насажденными, и лугами со стадами верблюдов, лошадей, рогатого скота и овец» [4, с. 222]. Трудно найти более поэтичные и точные слова, чем эти, написанные самим художником.

Кяхта оказалась последним пунктом на русско-китайской границе, куда прибыло посольство. Поселение было небольшим, но, основанное в 1743 году, оно оставалось на протяжении последующего столетия (до 1858 года) единственным пограничным пунктом для провоза чая. Свое значение как торгового пути Кяхта не потеряла и в начале XX века. В упомянутом «Письме молодого художника» есть описание этой слободы, которая насчитывала около четырехсот домов и стояла «между горами в лощине, река здесь такая большая, что надлежит довольно высоко поднять ногу, чтобы перешагнуть через нее» [2, с. 100]. Понятно, что отказать автору в чувстве юмора трудно, но пейзаж, изображающий «Вид Кяхты и китайской границы» (1806, Государственный Эрмитаж) доносит до нас облик этой слободы с одноэтажными домами, стоящими по высоким берегам реки, и ТроицкоСавского монастыря, расположенного на левом берегу реки. Дальние горы были уже территорией Китая. Вновь пейзажный природный мотив и бытовые сценки занимают воображение художника. Но теперь они любопытны своей этнографией. Это не только особое женское одеяние, но и верблюды, впряженные в двухколесную телегу. Подобные экзотические мотивы придавали пейзажам особый местный колорит.

Как известно, Российское посольство доехало до города Урги (Улан-Батор), где вновь остановилось на длительное время в связи с невозможностью достичь соглашения с китайскими властями о церемониале его пребывания.

Посольство расположилось лагерем близ Урги, и Мартынов неоднократно писал его во время различных церемоний, как и сам город. Одна из акварелей «Вид города Урги и жительство великого Ламы» (1806-1810, ГЭ) свидетельствует об интересе художника к этнографическим особенностям этого края. Хотя сам город и не очень велик, но в нем было несколько буддистских храмов, монастырей, именно там проживал великий Лама. Мартынов пишет его резиденцию на фоне высоких гор, окружающих город и утопающих в голубовато-золотистой дымке. С большим вниманием и точностью он воспроизводит непривычную для русского глаза архитектуру, эффектно с угла изображает основной комплекс обитания Ламы. Это четыре перекрытых круглым куполом строения, которые окружают центральное, более массивное и объ- 
емное. Четыре высокие цилиндрические башни придают комплексу законченный вид. Вокруг - различного назначения постройки с крышами, которые завершаются, как в пагодах, приподнятым краем. Тут уже нельзя говорить о фигурах персонажей как о стаффажных, герои живут в этой среде, беседуют, гуляют, работают, и каждая из групп трактована естественно, с большим вниманием. Этот пейзаж мало напоминает те выстроенные композиции, которые предпочитал писать художник, руководствуясь натурными зарисовками 1805 года.

В завершение следует отметить некоторые тенденции в развитии русской пейзажной живописи начала XIX века.

Известно, что в конце XVIII столетия пейзажи мыслились как часть интерьера, и зачастую заказчик предлагал размер, сюжет и даже диктовал такие особенности, как освещение. Другими словами, картина точно была рассчитана на определенное место в доме. Но в начале следующего века художники перестают «сочинять» пейзажный мотив, опираясь на тот или иной конкретный вид, а начинают более пристально вглядываться в природу. Составленные на основе путевых зарисовок альбомы акварелей, офортов и последующие живописные работы Мартынова являются одним из первых примеров живого наблюдения, «осознания жизни природы». Пейзаж постепенно отходит от привычной декоративной неподвижности, в нем начинает проявляться натуралистическое начало (пока еще не реалистическое), натурное письмо укореняется в академическом классицизме. В пейзажах начала XIX века представлены уже не величественные видовые панорамы, но открывается переданный художником естественный образ того или иного края. Природа перестает быть просто абстрактным видом, она связывается со временем и пространством, это уже не «подстриженный» под стандартный декоративный образец мотив, но образ подлинной русской природы. В дальнейшем в пейзажах «созерцается не столько природа, сколько жизнь на земле» [5, с. 49].

Стоит так же отметить, что стаффажные фигуры в композициях Мартынова еще не составляют организованного действия и не являются персонажами жанровой сцены. Они лишь несколько оживляют пейзаж. В этом художник остается верен классицистическим канонам. В более поздних видах Санкт-Петербурга Мартыновым будет представлен обыденный городской пейзаж, где силуэты горожан перестают быть просто стаффажем.

В целом посольство графа Ю.А. Головкина в Китай с политической и экономической точки зрения не увенчалось успехом. В настоящее время упоминания об этой экспедиции связаны именно с художественным наследием, оставленным А.Е. Мартыновым и его младшими коллегами. Яркие и самобытные образы дальних уголков российской земли, воплощенные в живописных и графических работах художника, являются одной из важнейших составляющих его творческого наследия.

\section{Список литературы}

1. Мартынов А.Е. Живописное путешествие при Российском посольстве в Китай в 1805-м году. Альбом с рисунками и текстом. - СПб., 1814-1819.

2. Письмо молодого художника из Кяхты к своему приятелю // Лицей. Журнал Ивана Мартынова. - Ч. 3. - Кн. 3. - СПб., 1806.

3. Федоров-Давыдов А.А. Русский пейзаж XVIII - начала XIX века. - М.: Искусство, 1953.

4. Мартынов А.Е. Живописное путешествие от Москвы до китайской границы. Альбом офортов. - Спб.: Типография А. Плюшара, 1819.

5. Манин В.С. Русская пейзажная живопись. Конец XVIIIXIX век. - СПб.: Аврора, 2012. 